\title{
Pengaruh Model Pembelajaran Children's Learning in Science berbantuan Media Audio Visual terhadap Kompetensi Pengetahuan IPA
}

\author{
N. P. E. Rositayani' ${ }^{*}$, D.B.K.N S. Putra², I.B.G.S. Abadi ${ }^{3}$ \\ 1,2,3 Jurusan Pendidikan Guru Sekolah Dasar (PGSD), Universitas Pendidikan Ganesha, Singaraja, Indonesia.
}

\author{
A R T I C L E I N F O \\ Article history: \\ Received 19 May 2018 \\ Received in revised form \\ 07 June 2018 \\ Accepted 10 July 2018 \\ Available online 20 August \\ 2018 \\ Kata Kunci: \\ children's learning in \\ science, audio visual, \\ kompetensi pengetahuan \\ IPA \\ Keywords: \\ children's learning in \\ science, audio visual, \\ knowledge competence of \\ science.
}

\begin{abstract}
A B S T R A K
Penelitian ini bertujuan untuk mengetahui perbedaan yang signifikan kompetensi pengetahuan IPA antara siswa yang dibelajarkan menggunakan model pembelajaran children's learning in science berbantuan media audio visual dan siswa yang dibelajarkan menggunakan pembelajaran konvensional pada siswa kelas IV SD Gugus Untung Surapati Denpasar Timur. Jenis penelitian ini adalah penelitian kuantitatif dengan rancangan penelitian quasi-experimental design dengan bentuk nonequivalent control group design. Populasi dari penelitian ini adalah seluruh siswa kelas IV SD Gugus Untung Surapati Denpasar Timur sebanyak 205 siswa. Pengambilan sampel menggunakan teknik random sampling. Sampel penelitian ini adalah siswa kelas IV SD Negeri 9 Sumerta yang dijadikan sebagai kelompok eksperimen dan siswa kelas IV SD Negeri 6 Sumerta yang dijadikan sebagai kelompok kontrol. Data mengenai kompetensi pengetahua IPA siswa kelas IV dikumpulkan dengan menggunakan instrumen berupa tes objektif pilihan ganda biasa. Berdasarkan hasil analisis data diperoleh rata-rata gain skor kelompok eksperimen $\left(X_{-1}^{-1}\right)$ dan kelompok kontrol ( $X^{-} 2$ ), yaitu $0,57>0,45$. Melalui uji hipotesis diperoleh thitung $>$ ttabel, yaitu $2,4>1,994$ dengan $\mathrm{dk}=70$ dan taraf signifikansi $5 \%$ maka Ho ditolak dan Ha diterima. Dengan demikian dapat disimpulkan bahwa model pembelajaran children's learning in science berbantuan media audio visual berpengaruh terhadap kompetensi pengetahuan IPA siswa kelas IV SD.
\end{abstract}

\begin{abstract}
A B S T R A C T
The purpose of this research was to know the significant difference of science knowledge competence between students who taught using learning model of children's learning in science assisted by audio visual media and students who taught using conventional learning in fourth grade students of SD Gugus Untung Surapati Denpasar Timur. The type of this research was quantitative research with quasi-experimental design with nonequivalent control group design. Population of this research were all student of fourth grade of elementary school of Gugus Untung Surapati Denpasar Timur as 205 students. Sampling using random sampling technique. The sample of this research was the fourth grader of SD Negeri 9 Sumerta which used as experimental group and fourth grade students of SD Negeri 6 Sumerta which become the control group. Data on the competence of science students knowledge of grade IV is collected by using the instrument of ordinary double choice objective test. Based on the result of data analysis, the average gain of experiment group score $\left(X_{-}^{-} 1\right)$ and control group ( $X_{-}^{-} 2$ ), that is $0,57>0,45$ Through hypothesis test obtained thitung $>$ ttable, that is $2,4>1,994$ with $\mathrm{dk}=70$ and significance level $5 \%$ then $\mathrm{Ho}$ reject and $\mathrm{Ha}$ accept. Thus it can be concluded that the learning model of children's learning in science assist audio visual media influence on science knowledge competence of fourth grade students of SD.
\end{abstract}




\section{Pendahuluan}

Penerapan kurikulum merupakan salah satu hal yang sedang dihadapi oleh Indonesia, kurikulum yang sering berubah-ubah dianggap kurang efektif dalam pelaksanaan proses pembelajaran pada kurikulum tersebut. Ketika terjadi perubahan pada kurikulum, maka terjadi perubahan pula pada strategi mengajar yang mengakibatkan kebingungan terhadap guru sebagai pendidik dan siswa sebagai terdidik. Untuk setiap perubahan kurikulum tentunya memerlukan banyak waktu yang digunakan untuk setiap penerapannya. Hal ini dilihat dari penerapan setiap kurikulum yang akan selalu diawali dengan adanya sosialisasi kurikulum, pelatihan, hingga pemahaman oleh guru dan siswa, sehingga memerlukan waktu yang cukup lama hingga pelaksanaan kurikulum tersebut dapat dilaksanakan sesuai dengan tujuan dalam penerapannya.

Selanjutnya, rendahnya prestasi pendidikan di Indonesia dikarenakan sistem pembelajaran di sekolah yang kurang efektif dan sumber daya manusia yang masih rendah, hal ini dapat dibuktikan dengan output pendidikan yang dihasilkan. Hal tersebut dilihat dari siswa yang kurang mampu mandiri, sehingga keaktifan siswa kurang, dan belum mampu membangun keingintahuannya. Siswa lebih banyak menghafal suatu pembelajaran daripada menalar, dalam hal ini siswa sulit untuk menjawab pertanyaan yang membutuhkan penalaran. Pada umumnya, siswa sebagai terdidik kurang menggali informasi melalui membaca atau sumber lainnya, hanya mengandalkan informasi yang diberikan oleh guru sebagai pendidik, dan menganggap guru merupakan pusat informasi satu-satunya.

Salah satu permasalahan pendidikan ini dapat dilihat di Bali pada khususnya. Dari segi pemerataan penerapan kurikulum yang saat ini dilaksanakan. Belum sepenuhnya kabupaten di Bali melaksanakan kurikulum yang telah dibenahi, yaitu kurikulum 2013. Selanjutnya, menurut Ikhtisar Data Pendidikan Tahun 2016/2017, Provinsi Bali sebanyak 2.193 siswa pada jejang Sekolah Dasar (SD) harus menghadapi pengulangan pada jenjang tersebut dan sebanyak 188 siswa mengalami putus sekolah. Adanya siswa yang mengalami putus sekolah, dilatar belakangi oleh berbagai faktor. Dan siswa yang mengalami pengulangan dapat diakibatkan oleh strategi belajar yang dilakukan oleh siswa di sekolah, yang mana siswa lebih banyak menghafal pembelajaran daripada memahami konsep pembelajaran tersebut serta mengkonstruksi pengetahuannya. Kemudian, fasilitas sarana dan prasarana yang disediakan oleh pemerintah disetiap kabupaten/kota madya tentu ada perbedaan. Kurangnya sarana dan prasarana penunjang, dapat menghambat proses pembelajaran di sekolah. Salah satu muatan materi yang memerlukan sarana dan prasarana adalah muatan materi Ilmu Pengetahuan Alam (IPA). Sarana dan prasarana yang memadai dapat menunjang kompetensi pengetahuan IPA siswa. "Kompetensi pengetahuan merefleksikan konsep-konsep keilmuan yang harus dikuasai oleh peserta didik melalui proses belajar mengajar" (Kunandar, 2014:165). Kemudian, "IPA merupakan ilmu yang pada awalnya diperoleh dan dikembangkan berdasarkan percobaan (induktif) namun pada perkembangan selanjutnya IPA juga diperoleh dan dikembangkan berdasarkan teori (deduktif)" (Wisudawati dan Sulistyowati, 2017:22). Jadi, kompetensi pengetahuan IPA dapat diartikan kompetensi pengetahuan yang merefleksikan konsep-konsep keilmuan yang diperoleh berdasarkan percobaan dan teori.

Berdasarkan hasil pengamatan yang telah dilaksanakan pada tanggal 17 Januari 2018 sampai 19 Januari 2018 di SD Negeri di Gugus Untung Surapati Denpasar Timur ditemukan bahwa, SD Negeri di gugus tersebut dalam pelaksanaan pembelajarannya masih terkesan teacher center bukan student center, dimana guru masih menjadi pusat informasi bagi siswa dan siswa hanya mencari serta menunggu informasi yang diberikan oleh guru, sehingga terkesan siswa kurang kreatif dalam memperoleh informasi. Kemudian, kurang optimalnya penggunaan sarana sebagai media penunjang pembelajaran yang ada di sekolah. Di samping itu, kurangnya variasi pembelajaran membuat pembelajaran monoton dan membosankan. Hal tersebut dapat mempengaruhi keingintahuan dan pemahaman siswa terhadap kompetensi pengetahuan IPA secara khususnya.

Melihat kejadian tersebut, salah satu model pembelajaran yang sesuai dengan pemaparan tersebut dan diyakini dapat mempengaruhi kompetensi IPA siswa lebih baik yaitu model pembelajaran children's learning in science (CLIS). Model pembelajaran CLIS merupakan "model pembelajaran yang berusaha mengembangkan ide/gagasan siswa tentang suatu masalah tertentu dalam pembelajaran serta merekonstruksi ide/gagasan berdasarkan hasil pengamatan atau percobaan" (Samatowa, 2010:74). Selain itu, model pembelajaran CLIS merupakan "model pembelajaran yang mempunyai karakteristik yang dilandasi paradigma kontruktivisme dengan memperhatikan pengetahuan awal siswa" (Wijayanti, 2010:2). Samatowa (2016) langkah-langkah pelaksanaan model ini, yaitu : (1) orientasi, (2) pemunculan gagasan, (3) penyusunan ulang, (4) penerapan gagasan, dan (5) pemantapan gagasan. Jadi model pembelajaran CLIS dalam penerapannya memperhatikan pengetahuan awal siswa untuk mengembangkan gagasannya. Model pembelajaran ini memiliki keunggulan yang diyakini dapat mempengaruhi kompetensi pengetahuan, khususnya IPA. 
Untuk mempermudah siswa dalam mengembangkan gagasan, model pembelajaran CLIS dibantu dengan penggunaan media audio visual. Media audio visual merupakan "media yang dapat menampilkan unsur gambar dan suara secara terpadu pada saat mengomunikasikan pesan atau informasi" (Wati, 2016:44). Selain itu, media audio visual adalah "media pembelajaran yang berisi suara dan gambar bergerak" (Suwitri, 2016:4). Kelebihan dari penggunaan media audio visual adalah untuk penyampaian guru menjelaskan yang kompleks ke sederhana, dapat digunakan untuk klasikal atau individual dan dapat digunakan secara berulang-ulang. Jadi media audio visual merupakan media yang dapat menampilkan unsur suara dan gambar bergerak yang dapat digunakan berulang-ulang. Penerapan model pembelajaran CLIS berbantuan media audio visual diyakini dapat membantu siswa dalam merekonstruksi pengetahuannya dengan memanfaatkan media gambar bergerak dan suara (audio visual) sebagai penyampaian materi pembelajaran. Berdasarkan uraian tersebut, maka pada kesempatan ini diadakan penelitian dengan judul Pengaruh Model Pembelajaran Children's Learning In Science Berbantuan Media Audio Visual Terhadap Kompetensi Pengetahuan IPA Siswa Kelas IV SD Gugus Untung Surapati Denpasar Timur.

Berdasarkan uraian tersebut, maka tujuan penelitian ini, yaitu 1) untuk mendeskripsikan kompetensi pengetahuan IPA siswa kelas IV SD Gugus Untung Surapati Denpasar Timur yang dibelajarkan menggunakan model pembelajaran children's learning in science berbantuan media audio visual, 2) untuk mendeskripsikan kompetensi pengetahuan IPA siswa kelas IV SD Gugus Untung Surapati Denpasar Timur yang dibelajarkan menggunakan pembelajaran konvensional. Dan 3) untuk mengetahui perbedaan yang signifikan terhadap kompetensi pengetahuan IPA antara siswa yang dibelajarkan menggunakan model pembelajaran children's learning in science berbantuan media audio visual dan siswa yang dibelajarkan menggunakan pembelajaran konvensional pada siswa kelas IV SD Gugus Untung Surapati Denpasar Timur.

Di dalam kurikulum 2013, aspek tersebut dinyatakan di dalam rumusan kompetensi inti yang dinotasikan yaitu, Kompetensi Inti-1 (KI-1) untuk kompetensi sikap spiritual; Kompetensi Inti-2 (KI-2) untuk kompetensi sikap sosial; Kompetensi Inti-3 (KI-3) untuk penguasaan kompetensi pengetahuan; dan Kompetensi Inti-4 (KI-4) untuk kompetensi keterampilan. Salah satu kompetensi yang dapat diketahui hasilnya setelah melaksanakan proses pembelajaran adalah kompetensi pengetahuan. "Kompetensi pengetahuan merefleksikan konsep-konsep keilmuan yang harus dikuasai oleh peserta didik melalui proses belajar mengajar" (Kunandar, 2014:165). Dimensi pengetahuan pada tingkat sekolah dasar hanya mencakup faktual dan konseptual, dikarenakan karakteristik siswa di SD termasuk operasional kongkret yang belum bisa untuk berpikir formal. Salah satu muatan materi yang terdapat dalam kompetensi pengetahuan, yaitu ilmu pengetahuan alam (IPA). Samatowa (2016:3), menyatakan "Ilmu pengetahuan alam merupakan terjemahan kata-kata dalam bahasa Inggris yaitu natural science, artinya ilmu pengetahuan alam (IPA). Berhubungan dengan alam atau bersangkut paut dengan alam, science artinya ilmu pengetahuan". Ada pula, IPA merupakan "rumpun ilmu, memiliki karakteristik khusus yaitu mempelajari fenomena alam yang faktual, baik berupa kenyataan atau kejadian dan hubungan sebab-akibatnya" (Wisudawati dan Eka, 2015:22). Menurut pendapat tersebut dapat disimpulkan bahwa IPA adalah sebagai suatu ilmu yang mempelajari fenomena alam atau peristiwa-peristiwa yang terkait dengan alam. Dan IPA membahas tentang gejala-gejala alam yang disusun secara sistematis yang didasarkan pada hasil percobaan dan pengamatan yang dilakukan oleh manusia.

Berdasarkan uraian tersebut, dapat dirangkum bahwa kompetensi pengetahuan IPA adalah kemampuan yang kompleks dimiliki siswa menyangkut tingkat pencapaian atau penguasaan terhadap suatu materi pembelajaran IPA. Model pembelajaran CLIS merupakan "model pembelajaran yang berusaha mengembangkan ide/gagasan siswa tentang suatu masalah tertentu dalam pembelajaran serta merekonstruksi ide/gagasan berdasarkan hasil pengamatan atau percobaan" (Samatowa, 2016:74). Dapat dikatakan model ini menganut pandangan konstruktivisme. Model pembelajaran CLIS lebih menekankan pada penyempurnaan dalam mendapatkan ide dan menyesuaikan dengan ilmu pengetahuan yang ada yang selanjutnya dikemukakan dengan pendapat sendiri.

Samatowa (2016) model CLIS terdiri atas lima tahap utama, yakni: (1) orientasi atau orientation; (2) pemunculan gagasan atau elicitation of ideas; (3) penyusunan ulang atau restructuring of ideas; (4) penerapan gagasan atau application of ideas; (5) pemantapan gagasan atau review change in ideas. Tahap penyusunan ulang gagasan masih dibedakan atas tiga bagian, yaitu : (a) pengungkapan dan pertukaran gagasan atau clarification and exchange; (b) pembukaan pada situasi konflik atau exposure to conflict situation; dan (c) konstruksi gagasan baru dan evaluasi atau construction of new ideas and evaluation.

Keunggulan model pembelajaran CLIS menurut Anggriani (2014), yaitu : (1) gagasan anak lebih mudah dimunculkan; (2) membiasakan siswa untuk belajar mandiri dalam memecahkan masalah, (3) menciptakan kreativitas siswa untuk belajar mandiri. Dalam melakasanakan pembelajaran perlu adanya media pembelajaran yang dapat menunjang proses pembelajaran menjadi efektif dan menarik. Media pembelajaran merupakan penunjang proses pembelajaran di kelas, salah satu media pembelajaran yang dapat digunakan yaitu media audio visual. Media audio visual merupakan "media yang dapat menampilkan 
unsur gambar dan suara secara terpadu pada saat mengomunikasikan pesan atau informasi" (Wati, 2016:44).

Rate Rusmala Sari Gani (2015) menyatakan, Berdasarkan hasil analisis data penelitian dan pembahasan maka dapat diambil kesimpulan sebagai berikut: (1) Aktivitas bela jar siswa selama mengikuti pembela jaran fisika menggunakan model pembelajaran CLIS dengan orientasi melalui observasi gejala fisis dalam pembelajaran IPA-Fisika siswa kelas VIII SMPN 1 Kunir tahun ajaran 2013/2014 termasuk dalam kriteria sangat aktif. Darmawati. N P (2016) juga menyatakan, Berdasarkan hasil penelitian dan pembahasan dapat dikemukakan kesimpulan sebagai berikut. 1) Terdapat perbedaan sikap ilmiah antara kelompok siswa yang dibelajarkan menggunakan model pembelajaran Children Learning in Science (CLIS) berbantuan metode Talking Stick dengan kelompok siswa yang dibelajarkan menggunakan model pembelajaran konvensional dalam pembelajaran IPA siswa kelas V Gugus 8 Jagadhita Kecamatan Kubutambahan. Asih Asih (2014) Menyatakan, aktivitas guru dan siswa dalam kegiatan pembelajaran siklus I dan siklus II meningkat dari kategori cukup ke kategori sangat baik. Kemudian untuk hasil tes pada siklus I diperoleh ketuntasan klasikal 65,00\% dan daya serap klasikal sebesar 64,7\%. Sedangkan pada siklus II diperoleh ketuntasan klasikal $85.00 \%$ dan daya serap klasikal sebesar $75.00 \%$. Ketuntasan belajar klasikal yang diperoleh pada siklus II telah memenuhi standar ketuntasan belajar klasikal yang telah ditetapkan yaitu di atas 70\%. Penelitian ini dapat disimpulkan bahwa dengan penerapan model pembelajaran Children Learning in Science (CLIS) dapat meningkatkan hasil belajar fisika pada siswa kelas XI MIA SMA Negeri 8 Palu.

Hal senada juga dikemukakan oleh Ali Ismail (2017) Menyatakan, Berdasarkan hasil analisis data diperoleh bahwa nilai rata-rata gain yang dinormalisasi untuk kelas eksperimen ialah 0,57 dengan kategori sedang dan nilai rata-rata gain yang dinormalisasi untuk kelas kontrol ialah 0,49 dengan kategori sedang. Perbandingan nilai ini secara langsung menunjukkan bahwa penggunaan model pembelajaran Children Learning in Science (clis) berbantuan multimedia dapat lebih efektif meningkatkan keterampilan proses sains siswa pada konsep fluida statis dibandingkan dengan pembelajaran konvensional berbantuan multimedia. Arisantiani N K (2017) juga menyatakan, Hasil penelitian menunjukkan bahwa terdapat perbedaan signifikan kompetensi pengetahuan IPA antara kelompok siswa yang dibelajarkan menggunakan model pembelajaran CLIS berbantuan media lingkungan dengan kelompok siswa yang dibelajarkan menggunakan pembelajaran konvensional pada kelas IV SD Gugus Yos Sudarso Kecamatan Denpasar Selatan. Dapat disimpulkan bahwa penerapan model pembelajaran CLIS berbantuan media lingkungan berpengaruh terhadap kompetensi pengetahuan IPA pada siswa kelas IV SD Gugus Yos Sudarso Kecamatan Denpasar Selatan tahun pelajaran 2016/2017.

Model pembelajaran CLIS berbantuan media audio visual merupakan model pembelajaran yang dapat membantu siswa dalam merekonstruksi pengetahuan yang didapatnya dengan mengoptimalkan indra penglihatan dan pendengaran melalui media audio visual sebagai sarana informasi.

\section{Metode}

Penelitian ini dilaksanakan di kelas IV SD Negeri Gugus Untung Surapati Kecamatan Denpasar Timur. jenis penelitian yang dilakukan adalah penelitian kuantitatif dengan rancangan penelitian yang digunakan yaitu rancangan eksperimen kuasi (Quasi-experimental Design) dengan bentuk Nonequivalent Control Group Design. Rancangan ini terdapat dua kelompok, yakni kelompok eksperimen dan kelompok kontrol. Kelompok tersebut sama-sama memperoleh pretest dan posttest.

Populasi penelitian ini adalah seluruh siswa kelas IV SD Gugus Untung Surapati Denpasar Timur yang tersebar di enam SD Negeri sebanyak 205 siswa. Sampel adalah "suatu kelompok yang lebih kecil atau bagian dari populasi secara keseluruhan" (Setyosari, 2015:221). Sedangkan menurut Sugiyono (2009:118), "Sampel adalah bagian dari jumlah dan karakteristik yang dimiliki oleh populasi tersebut. Jadi, dapat dirangkum sampel adalah bagian dari populasi tersebut. Dalam pengambilan sampel penelitian ini menggunakan teknik Random Sampling, (Sugiyono, 2015:132) menyatakan bahwa "Random sampling adalah cara pengambilan sampel secara acak". "Sampling random merupakan cara pengambilan sampel dengan memberikan kesempatan yang sama pada anggota populasi untuk diambil menjadi anggota sampel” (Agung, 2014:71). Dengan demikian, dalam penelitian ini setiap kelas mendapatkan kesempatan yang sama untuk dijadikan sampel.

Sampel ditentukan dengan cara pengundian kelas. Pengundian dilakukan dengan cara menuliskan nama kelas serta sekolah yang ada di Gugus Untung Surapati Denpasar Timur dalam selembar kertas yang jumlahnya enam, karena SD yang terdapat pada populasi tersebut berjumlah enam. Kemudian kertas tersebut digulung dan masukkan ke dalam wadah seperti toples, yang mana tutup toples tersebut telah diberi lubang. Wadah yang berisi gulungan kertas tersebut dikocok dan keluarkan dua gulungan kertas tersebut. Nama kelas dan sekolah pada kertas yang telah dikeluarkan tersebutlah yang dijadikan sampel 
penelitian. Setelah mendapatkan hasil undian, pretest diberikan untuk penyetaraan kelas, nilai atau skor dari hasil pretest dianalisis menggunakan uji-t. peneliti melakukan pengundian kembali dari kedua sampel tersebut untuk menentukan kelompok eksperimen dan kelompok kontrol. Data yang akan dicari dalam penelitian ini adalah kompetensi pengetahuan IPA siswa kelas IV SD Gugus Untung Surapati Denpasar Timur. Metode yang digunakan untuk pengumpulan data yaitu menggunakan tes. "Tes merupakan sekumpulan pertanyaan yang digunakan untuk mengumpulkan data mengenai kemampuan kognitif siswa sebelum atau setelah proses pembelajaran berlangsung" (Jakni, 2016:98). Jadi, tes adalah sekumpulan pertanyaan yang terkait dengan data yang diinginkan. Instrumen yang digunakan, yaitu tes objektif. Bentuk tes objektif tersebut adalah pilihan ganda biasa yang meliputi empat pilihan jawaban (a, b, c, atau d). Kompetensi pengetahuan yang diukur terdiri dari mengingat (C1), memahami (C2), menerapkan (C3), dan menganalisis (C4) dengan dimensi pengetahuan khususnya didi SD adalah pengetahuan faktual dan konseptual. pengujian instrumen penelitian, yaitu uji validitas, uji reliabilitas, uji daya beda, dan tingkat kesukaran. Instrumen yang di uji coba berjumlah 50 butir soal dan yang layak digunakan setelah dilakukan uji instrumen berjumlah 36 butir soal.

Teknik analisis data yang digunakan, yaitu statistik deskriptif dan inferensial. Statistik inferensial meliputi statistik parametrik dan non parametrik. Statistik deskriptif adalah cara mendeskripsikan data yang terkumpul menggunakan rumus statistik. "Statistik deskriptif adalah statistik yang digunakan untuk menganalisis data dengan cara mendeskripsikan atau menggambarkan data yang telah terkumpul” (Jakni, 2016:103). Statistik inferensial adalah "teknik statistik yang digunakan untuk menganalisis data sampel dan hasilnya diberlakukan untuk populasi” (Jakni, 2016:122). Hasil dari nilai pretest dan posttest akan dianalisis menggunakan analisis statistik parametrik yaitu uji-t. sebelum melakukan analisis menggunakan uji-t, terlebih dahulu melakukan uji prasyarat analisis yaitu uji normalitas data dan uji homogenitas variansi. Nilai pretest tersebut dapat juga dilakukan normalisasi dengan nilai postest. Nilai tersebut dinormalisasikan dengan menggunakan gain skor ternormalisasi (Normalizzed Gain Score).

Adapun hipotesis penelitian yang akan diuji, yaitu : Tidak terdapat perbedaan yang signifikan terhadap kompetensi pengetahuan IPA antara kelompok siswa yang dibelajarkan menggunakan model pembelajaran children's learning in science berbantuan media audio visual dan kelompok siswa yang dibelajarkan melalui pembelajaran konvensional kelas IV SD Gugus Untung Surapati Denpasar Timur.

\section{Hasil dan Pembahasan}

Hasil penelitian ini memaparkan mengenai nilai rata-rata (mean), median, modus (mode),variansi, dan standar deviasi dari data gain skor ternormalisasi kompetensi pengetahuan IPA. Data yang diperoleh dalam penelitian ini dikelompokkan menjadi dua, yaitu : data kompetensi pengetahuan IPA kelompok eksperimen dan data kompetensi pengetahuan IPA kelompok kontrol. Data GSn kompetensi pengetahuan IPA kelompok eksperimen diperoleh nilai rata-rata adalah 0,57. Nilai median adalah 0,57. Nilai modus adalah 0,57 . Nilai variansii adalah 0,04 . Nilai standar deviasi adalah 0,20 . Rata-rata GSn kompetensi pengetahuan IPA kelompok eksperimen mendapat predikat sedang, sehingga dikatakan pembelajaran atau perlakuan yang diberikan berhasil. Dan data GSn kompetensi pengetahuan IPA kelompok kontrol diperoleh nilai rata-rata adalah 0,45. Nilai median adalah 0,42. Nilai modus adalah 0,40. Nilai variansi adalah 0,04. Dan nilai standar deviasi adalah 0,21. Rata-rata GSn kompetensi pengetahuan IPA kelompok kontrol mendapat predikat sedang.

Tabel 1. Deskripsi Data GSn Komptensi Pengetahuan IPA Kelompok Eksperimen dan Kontrol.

\begin{tabular}{ccc}
\hline Hasil Analisis & Kelompok Eksperimen & Kelompok Kontrol \\
Rata-rata & 0,57 & 0,45 \\
Median & 0,57 & 0,42 \\
Modus & 0,57 & 0,40 \\
Variansii & 0,04 & 0,04 \\
Standar Deviasi & 0,20 & 0,21 \\
\hline
\end{tabular}

Tabel 2. Kelompok Predikat Kriteria Peningkatan Gain Skor Kompetensi Pengetahuan IPA Kelompok Eksperimen dan Kontrol

\begin{tabular}{cccccc}
\hline \multirow{2}{*}{$\begin{array}{c}\text { Kriteria Peningkatan } \\
\text { Gain Skor }\end{array}$} & Predikat & \multicolumn{2}{c}{ Eksperimen } & \multicolumn{2}{c}{ Kontrol } \\
\cline { 3 - 6 } & & Frekuensi & Persentase & Frekuensi & Persentase \\
\hline$G \geq 0,7$ & Tinggi & 3 & $9 \%$ & 9 & $23 \%$ \\
\hline $0,3 \leq G<0,7$ & Sedang & 23 & $70 \%$ & 25 & $64 \%$ \\
\hline
\end{tabular}




\section{$G<0,3$}

Rendah

7

$21 \%$

5

$13 \%$

Adapun data GSn kompetensi pengetahuan IPA kelompok eksperimen dan kelompok kontrol disajikan dalam diagram lingkaran yang telah dikelompokkan sesuai dengan predikat yang diperoleh pada peningkatan gain skor.

\section{Diagram Lingkaran}

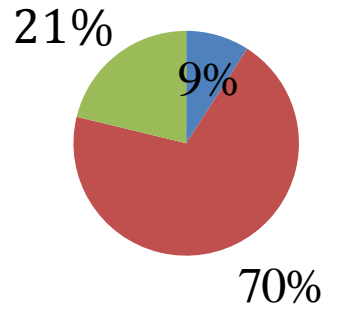

Tinggi

Sedang

Rendah

$70 \%$

Gambar 01. Diagram Lingkaran Data GSn Kompetensi Pengetahuan IPA Kelompok Eksperimen

\section{Diagram Lingkaran}

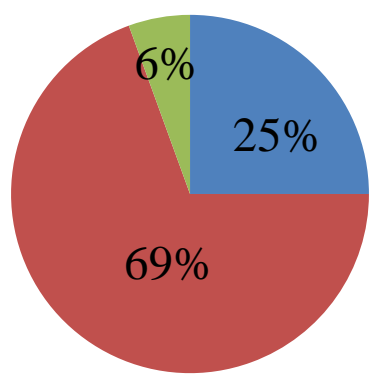

Tinggi

Sedang

Rendah

Gambar 02. Diagram Lingkaran Data GSn Kompetensi Pengetahuan IPA Kelompok Kontrol

Data yang diperoleh dari penelitian ini kemudian dianalisis menggunakan statistik melalui tahapan yang meliputi yaitu uji normalitas sebaran data, uji homogenitas variansi, dan uji hipotesis. Hasil uji normalitas kelompok eksperimen diperoleh Kolmogorov Smirnov (KS) hitung $\left(\mathrm{KS}_{\text {hitung }}=0,107\right)$ kemudian nilai tersebut dibandingkan dengan $\mathrm{KS}$ tabel $\left(\mathrm{KS}_{\text {tabel }}=0,231\right)$. Hal ini menunjukkan bahwa $\mathrm{KS}_{\text {hitung }}<\mathrm{KS}_{\text {tabel }}$ berarti data kompetensi pengetahuan IPA kelompok eksperimen berdistribusi normal. Hasil uji normalitas kelompok kontrol diperoleh $\mathrm{KS}_{\text {hitung }}\left(\mathrm{KS}_{\text {hitung }}=0,090\right)$ kemudian nilai tersebut dibandingkan dengan $\mathrm{KS}_{\text {tabel }}$ $\left(\mathrm{KS}_{\text {tabel }}=0,213\right)$. Hal ini menunjukkan bahwa $\mathrm{KS}_{\text {hitung }}<\mathrm{KS}_{\text {tabel }}$ berarti data kompetensi pengetahuan IPA kelompok kontrol berdistribusi normal.

Homogenitas variansi data kompetensi pengetahuan IPA dianalisis dengan uji F. Hasil analisis diperoleh $F_{\text {hitung }}=1,118$ dan $F_{\text {tabel }}=1,775$. Hal ini berarti $F_{\text {hitung }}<F_{\text {tabel }}$ sehingga data kedua kelompok memiliki variansi yang homogen. Hipotesis yang diuji dalam penelitian ini adalah Tidak terdapat perbedaan yang signifikan terhadap kompetensi pengetahuan IPA antara kelompok siswa yang dibelajarkan menggunakan model pembelajaran children's learning in science berbantuan media audio visual dan kelompok siswa yang dibelajarkan melalui pembelajaran konvensional kelas IV SD Gugus Untung Surapati Denpasar Timur. Analisis statistik yang digunakan untuk menguji hipotesis pada penelitian ini yaitu uji $t$ dengan rumus polled variansi. Kriteria pengujian yaitu jika $t_{\text {hitung }}>t_{\text {tabel }}$ maka $H_{o}$ ditolak. $t_{\text {tabel }}$ diperoleh dari tabel distribusi t pada taraf signifikansi 5\% dengan derajat kebebasan $(\mathrm{dk})=\mathrm{n}_{1}+\mathrm{n}_{2}-2$. Hasil analisis uji $\mathrm{t}$ kompetensi pengetahuan IPA disajikan pada tabel 03 yaitu sebagai berikut 
Tabel 3. Hasil analisis ujit kompetensi pengetahuan IPA

\begin{tabular}{|c|c|c|c|c|c|c|c|c|}
\hline No & Sampel & $\mathrm{n}$ & Dk & $\bar{X}$ & $s^{2}$ & $t_{\text {hitung }}$ & $t_{\text {tabal }}$ & Keterangan \\
\hline 1. & $\begin{array}{l}\text { Kelompok } \\
\text { Eksperimen }\end{array}$ & 33 & \multirow[t]{2}{*}{70} & 0,57 & 0,04 & \multirow{2}{*}{2,4} & \multirow[t]{2}{*}{1,994} & \multirow[t]{2}{*}{$H_{o}$ ditolak } \\
\hline 2. & Kelompok Kontrol & 39 & & 0,45 & 0,04 & & & \\
\hline
\end{tabular}

Berdasarkan uji hipotesis diperoleh $t_{\text {hitung }}=2,4$ dengan $\mathrm{dk}=33+39-2=70$ dan taraf signifikansi $5 \%$ diperoleh nilai $t_{\text {tabel }}=1,994$ sehingga $t_{\text {hitung }}=2,4>t_{\text {tabel }}=1,994$ maka Ho ditolak dan Ha diterima. Hal ini berarti terdapat perbedaan yang signifikan terhadap kompetensi pengetahuan IPA antara kelompok siswa yang dibelajarkan menggunakan model pembelajaran children's learning in science berbantuan media audio visual dan kelompok siswa yang dibelajarkan melalui pembelajaran konvensional kelas IV SD Gugus Untung Surapati Denpasar Timur. perolehan hasil perhitungan analisis data menunjukkan bahwa rata-rata GSn kompetensi pengetahuan IPA siswa yang mengikuti pembelajaran menggunakan model CLIS berbantuan media audio visual adalah 0,57 dan rata-rata GSn kompetensi pengetahuan IPA siswa yang mengikuti pembelajaran konvensional adalah 0,45. Dengan demikian terdapat pengaruh kompetensi pengetahuan IPA siswa kelas IV di SD Gugus Untung Surapati Denpasar Timur yang mengikuti pembelajaran dengan menggunakan model pembelajaran CLIS berbantuan media audio visual pada tema tersebut.

Dari perolehan kompetensi pengetahuan pada kedua kelompok dapat diketahui bahwa kedua kelompok yang awalnya memiliki kemampuan yang setara, kemudian setelah diberikan perlakuan pada kelompok eksperimen dengan model pembelajaran CLIS berbantuan media audio visual, sedangkan kelompok kontrol tidak diberikan perlakuan maka perolehan nilai kompetensi pengetahuan IPA mengalami perbedaan. Kompetensi pengetahuan IPA siswa pada kelompok eksperimen lebih baik apabila dibandingkan dengan kompetensi pengetahuan IPA siswa pada kelompok kontrol. Hal ini disebabkan oleh pembelajaran yang diterapkan pada kelompok eksperimen memiliki banyak kelebihan. Perbedaan yang signifikan kompetensi pengetahuan IPA antara kelompok eksperimen dengan kelompok kontrol dikarenakan pada kelompok eksperimen diberikan perlakuan sedangkan kelompok kontrol tidak diberikan perlakuan pada saat pembelajaran. Kelompok eksperimen diberikan perlakuan berupa model pembelajaran CLIS berbantuan media audio visual memiliki nilai rata-rata lebih tinggi dibandingkan dengan kelompok kontrol yang menerapkan pembelajaran konvensional.

\section{Simpulan dan Saran}

Berdasarkan uji hipotesis diperoleh thitung $=2,4$ dengan $\mathrm{dk}=33+39-2=70$ dan taraf signifikansi $5 \%$ diperoleh nilai ttabel $=1,994$ sehingga thitung $=2,4>$ ttabel $=1,994$ maka Ho ditolak dan Ha diterima. Hal ini berarti terdapat perbedaan yang signifikan terhadap kompetensi pengetahuan IPA antara kelompok siswa yang dibelajarkan menggunakan model pembelajaran children's learning in science berbantuan media audio visual dan kelompok siswa yang dibelajarkan melalui pembelajaran konvensional kelas IV SD Gugus Untung Surapati Denpasar Timur. perolehan hasil perhitungan analisis data menunjukkan bahwa rata-rata GSn kompetensi pengetahuan IPA siswa yang mengikuti pembelajaran menggunakan model CLIS berbantuan media audio visual adalah 0,57 dan rata-rata GSn kompetensi pengetahuan IPA siswa yang mengikuti pembelajaran konvensional adalah 0,45. Dengan demikian terdapat pengaruh kompetensi pengetahuan IPA siswa kelas IV di SD Gugus Untung Surapati Denpasar Timur yang mengikuti pembelajaran dengan menggunakan model pembelajaran CLIS berbantuan media audio visual pada tema tersebut.

Adapun saran yang dapat disampaikan berdasarkan hasil penelitian yang telah dilakukan yaitu : untuk guru agar lebih kreatif untuk memberikan fasilitas berupa sumber belajar dan kesempatan yang lebih besar bagi siswa pada pembelajaran dengan menggunakan model CLIS berbantuan media audio visual sehingga tercipta pembelajaran bermakna bagi siswa. Untuk kepala sekolah agar dapat menggunakan hasil penelitian ini sebagai pendukung sumber belajar guru dalam meningkatkan kualitas pembelajaran dengan menciptakan pembelajaran yang menggembirakan di sekolah sehingga sekolah mampu menghasilkan siswa yang memiliki output berkualitas. Dan untuk peneliti lain agar hasil penelitian ini digunakan sebagai referensi untuk melaksanakan penelitian selanjutnya atau menemukan inovasi kegiatan pembelajaran lainnya yang bermakna bagi siswa.

\section{Daftar Rujukan}

Agung, A.A Gede. 2006. Evaluasi Pendidikan. Singaraja: Universitas Pendidikan Ganesha.

Agung, A.A. Gede. 2011. Pengantar Evaluasi Pendidikan. Singaraja : Universitas Pendidikan Ganesha. 
Ali Ismail. 2017. Penerapan Model Pembelajaran Children Learning in Science (Clis) Berbantuan Multimedia untuk Meningkatkan Keterampilan Proses Sains Siswa SMA Pada Pokok Bahasan Fluida. JIPFRI: Jurnal Inovasi Pendidikan Fisika dan Riset Ilmiah STKIP Nurul Huda. Vol. 1 No. 2. (p) 83 - 87.

Anggriani, Putu Dian. (2014). "Pengaruh Model Pembelajaran Childrend Learning in Science dengan Media Konkret Terhadap Hasil Belajar IPA Siswa Kelas IV SD”. E-Journal Mimbar PGSD Universitas Pendidikan Ganesha, Vol. 2 No. 1.

Arikunto, Suharsimi. 2015. Dasar-dasar Evaluasi Pendidikan. Jakarta : Bumi Akasara.

Arisantiani, Ni Ketut. (2017). "Pengaruh Model Pembelajaran Childrens Learning in Science (CLIS) Berbantuan Media Lingkungan Terhadap Kompetensi Pengetahuan IPA". Journal of Education Technology, Vol. 1 No. 2.

Asih Asih, Fihrin Fihrin, Yusuf Kendek. 2014. Penerapan Model Pembelajaran Children Learning In Science (Clis) Untuk Meningkatkan Hasil Belajar Fisika Pada Siswa Kelas Xi Sma Negeri 8 Palu. Jurnal Pendidikan Fisika Tadulako. Vol 2, No 3.

Astiti, Ni Putu Mia. (2017). "Pengaruh Model Pembelajaran Children Learning in Science Berbasis Budaya Penyelidikan Terhadap Kompetensi Pengetahuan IPA". Journal of Education Technology, Vol. 1 No. 2.

Budiarti, Luh Putu Yudha. (2014)."Pengaruh Model Pembelajaran CLIS Terhadap Hasil Belajar IPA Siswa Kelas IV SD di Gugus III Kecamatan Busungbiu”. Jurnal Mimbar PGSD Universitas Pendidikan Ganesha Jurusan PGSD, Vol. 1.

Dantes. N. 2017. Desain Eksperimen dan Analisis Data. Depok : Rajawali Pers.

Darmawati. N P, I Md. Tegeh. Suarni N K. 2015. Pengaruh Model Pembelajaran Children Learning in Science Berbantuan Metode Talking Stick terhadap Sikap Ilmiah dan Penguasaan Konsep IPA Kelas V. Mimbar PGSD Undiksha. Vol 2, No 2.

Dewi, I Gst Ayu Apsari. (2014). "Pengaruh Model Pembelajaran CLIS Terhadap Pemahaman Konsep IPA Siswa Kelas V SD di Gugus VII Kecamatan Sawan”. E-Journal Mimbar PGSD Universitas Pendidikan Ganesha, Vol. 2 No. 1.

Dewi, Pande Nym. Tri Tresna. (2014). "Pengaruh Model Children's Learning in Science Berbantuan Media Powerpoint Terhadap Hasil Belajar IPA Siswa Kelas V SD". Jurnal Mimbar PGSD Universitas Pendidikan Ganesha. Vol. 2 No. 1.

Jakni. 2016. Metodologi Penelitian Eksperimen Bidang Pendidikan. Bandung: Alfabeta.

Kunandar. 2014. Penilaian Auntentik (Penilaian Hasil Belajar Siswa Berdasarkan Kurikulum 2013). Jakarta: Rajawali Persada.

Kurniasih, Imas \& Berlin Sani. 2014. Sukses Mengimplementasikan Kurikulum 2013 : Memahami Berbagai Aspek dalam Kurikulum 2013. Jakarta : Kata Pena.

Mairing, Jackson Pasini. 2017. Statistika Pendidikan. Yogyakarta: CV. Andi Yogyakarta.

Majid, Abdul dan Chaerul Rochman. 2015. Pendekatan Ilmiah dalam Implementasi Kurikulum 2013. Bandung: Remaja Rosdakarya.

Rate Rusmala Sari, Indrawati, Agus Abdul Gani. 2015. Model Pembelajaran Clis (Children Learning In Science) Dengan Orientasi Melalui Observasi Gejala Fisis Dalam Pembelajaran IPA-Fisika di SMP. Jurnal Pendidikan Fisika Universitas Jember. Vol. 3 No.4. hal 324-329.

Samatowa, Usman. 2011. Pembelajaran IPA di Sekolah Dasar. Jakarta : Indeks.

Samatowa, Usman. 2016. Pembelajaran IPA Di Sekolah Dasar. Jakarta : PT Indeks.

Sani, Ridwan Abdullah. 2015. Pembelajaran Saintifik untuk Implementasi Kurikulum 2013. Jakarta: Bumi Aksara.

Setyosari, Punaji H. 2015. Metode Penelitian Pendidikan \& Pengembangani. Jakarta :Prenadamedia.

Sudijono, Anas. 2011. Pengantar Evaluasi Pendidikan. Jakarta : PT. Raja Grafindo Persada.

Sugiyono. 2009. Metode Penelitian Pendidikan : Pendekatan Kuantitatif, Kualitatif, dan R\&D. Bandung: Alfabeta. 
Sugiyono. 2010. Metode Penelitian Pendidikan : Pendekatan Kuantitatif, Kualitatif, dan R\&D. Bandung: Alfabeta.

Supangat, Andi. 2008. Statistika : dalam Kajian Deskriptif, Inferensi, dan Nonparametrik. Jakarta : Kencana.

Susanti, Ni Luh Desi. (2014). "Model Pembelajaran CLIS Berbantuan Media Grafis Berpengaruh Terhadap Hasil Belajar IPA Siswa Kelas V SD Gugus Srikandi Denpasar Timur". E-Journal Mimbar PGSD Universitas Pendidikan Ganesha, Vol. 2 No. 1.

Suwitri, Ni Made. (2016). "Penerapan Pendekatan Saintifik Berbantuan Media Audiovisual dapat Meningkatkan Keaktifan dan Kompetensi Pengetahuan IPA Kelas IVA". E-Journal Mimbar PGSD Universitas Pendidikan Ganesha, Vol. 4 No. 1.

Wati, Ega Rima. 2016. Ragam Media Pembelajaran : Visual-Audio Visual-Komputer-Powerpoint-Interactive Video. Jakarta : Kata Pena.

Wisudawati, Asih Widi dan Eka Sulistyowati. 2015. Metodologi Pembelajaran IPA. Jakarta : Bumi Aksara.

Yusuf, Muri. 2015. Asesmen dan Evaluasi Pendidikan. Jakarta: Prenada Media Group. 